University of Nebraska - Lincoln

DigitalCommons@University of Nebraska - Lincoln

Faculty Publications from the Harold W. Manter Laboratory of Parasitology

8-1988

On the Status of Eimeria nieschulzi Oocysts Embedded in Resin Eleven Years Ago: A Permanent Method for Preserving Coccidian Oocysts

\author{
Alan A. Marchiondo \\ Fermenta Animal Health Company \\ Donald W. Duszynski \\ University of New Mexico, eimeria@unm.edu
}

Follow this and additional works at: https://digitalcommons.unl.edu/parasitologyfacpubs

Part of the Parasitology Commons

Marchiondo, Alan A. and Duszynski, Donald W., "On the Status of Eimeria nieschulzi Oocysts Embedded in Resin Eleven Years Ago: A Permanent Method for Preserving Coccidian Oocysts" (1988). Faculty Publications from the Harold W. Manter Laboratory of Parasitology. 170.

https://digitalcommons.unl.edu/parasitologyfacpubs/170

This Article is brought to you for free and open access by the Parasitology, Harold W. Manter Laboratory of at DigitalCommons@University of Nebraska - Lincoln. It has been accepted for inclusion in Faculty Publications from the Harold W. Manter Laboratory of Parasitology by an authorized administrator of DigitalCommons@University of Nebraska - Lincoln. 


\title{
On the Status of Eimeria nieschulzi Oocysts Embedded in Resin Eleven Years Ago: A Permanent Method for Preserving Coccidian Oocysts
}

\begin{abstract}
Alan A. Marchiondo* and Donald W. Duszynski, Department of Biology, The University of New Mexico, Albuquerque, New Mexico 87131. "Present address: Fermenta Animal Health Co., 7410 NW Tiffany Springs Pkwy., P.O. Box 901350, Kansas City, Missouri 64190-1350
\end{abstract}

\begin{abstract}
Sporulated oocysts of Eimeria nieschulzi that were fixed and mounted on glass slides in polymerized resin in 1976 are examined. Size, shape, and integrity of oocysts and sporocysts are compared to similar observations we made in 1977 and reported in 1978 (Journal of Parasitology 64: 163-164). Our conclusion is that the methods we reported on in 1978 provide one opportunity to produce permanent specimens of sporulated oocysts that could be made available for deposit in nationally accredited museums.
\end{abstract}

In 1978 we reported 2 methods to produce permanent slides of coccidian oocysts (Marchiondo and Duszynski, 1978) for light microscopy. Bandoni and Duszynski (1988) discuss the problems created in coccidian systematic studies by the failure of workers in the discipline to adhere to a type tradition when describing new species of coccidia from sporulated oocysts. They note that our preservation techniques and the use of good photomicrographs could help preserve key oocyst structures for later identification 


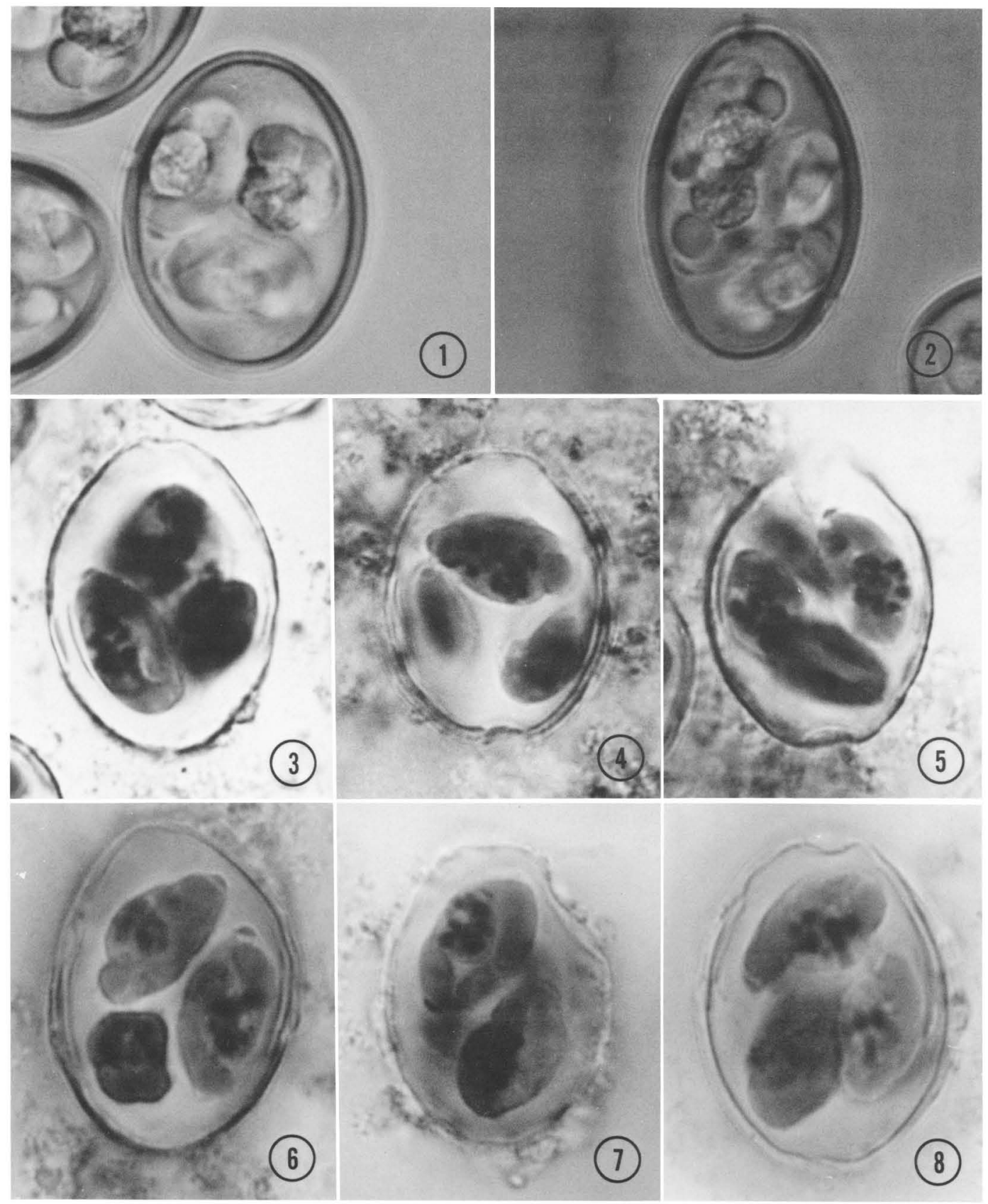

Figures 1-8. Photomicrographs of sporulated oocysts of Eimeria nieschulzi. $\times 1,800.1$, 2. Live oocysts showing some of the variation in shape seen in normal populations of $E$. nieschulzi. 3-5. Prints of negatives of oocysts embedded in resin (see Marchiondo and Duszynski, 1978) and photographed in 1977, about 15 mo after oocysts were mounted and polymerization occurred. 6-8. Oocysts on the same slide as oocysts in Figures $3-5$, but photographed in 1987, 11 yr after mounting and polymerization.

and that the effort to use such techniques by those who describe new species based on oocyst structure can help remedy the current lack of a type tradition in coccidian systematics. Thus, it seemed appropriate at this time to reexamine the slides we prepared more than a decade ago to determine whether or not the oocysts mounted on them have maintained their structural integ- 
TABLE I. Measurements of sporulated oocysts of Eimeria nieschulzi in 3 different groups: 2 batches of live oocysts of different ages; oocysts fixed, embedded, and mounted by 2 different techniques and measured in 1977; oocysts on the same slides as in 1977, but measured 10 yr later.*

\begin{tabular}{|c|c|c|c|c|c|c|}
\hline \multirow[b]{2}{*}{ Oocyst groups } & \multicolumn{3}{|c|}{ Oocyst } & \multicolumn{3}{|c|}{ Sporocyst } \\
\hline & Length & Width & $\mathrm{L} / \mathrm{W}$ & Length & Width & L/W \\
\hline \multicolumn{7}{|l|}{ Live oocysts } \\
\hline 4 mo old & $22.1(20-25)$ & $17.2(15-18)$ & 1.3 & $11.9(10-13)$ & $7.9(7-9)$ & 1.5 \\
\hline 40 mo old & $22.5(20-26)$ & $18.2(16-20)$ & 1.2 & $12.4(10-15)$ & $7.8(7-9)$ & 1.6 \\
\hline \multicolumn{7}{|l|}{1977 oocysts $\dagger$} \\
\hline kf-043-1‡ & $22.4(20-25)$ & $17.0(14-20)$ & 1.3 & $11.0(9-13)$ & $6.4(6-8)$ & 1.7 \\
\hline $\mathrm{kf}-063-2 \S$ & $21.8(19-24)$ & $16.9(15-20)$ & 1.3 & $10.4(9-12)$ & $6.3(6-8)$ & 1.65 \\
\hline \multicolumn{7}{|l|}{1987 oocysts } \\
\hline kf-043-1 & $23.3(20-26)$ & $17.5(16-19)$ & 1.3 & $11.1(9-12)$ & $6.4(5-8)$ & 1.7 \\
\hline kf-063-2 & $23.0(19-26)$ & $17.6(15-19)$ & 1.3 & $11.5(9-13)$ & $7.4(6-8)$ & 1.55 \\
\hline
\end{tabular}

* All measurements are means $(n=25)$ followed by the (ranges).

† Oocysts measured 15 mo after treatment/affixation to slides (see Marchiondo and Duszynski, 1978)

₹ Treatment group: $\mathrm{CO}_{2}(5 \%)$, glutaraldehyde $(15 \%), \mathrm{OsO}_{4}(2 \%)$, Epon 812 .

$\$$ Treatment group: $\mathrm{CO}_{2}(5 \%)$, Karnovsy's, $\mathrm{OsO}_{4}(2 \%)$, Spurr's.

rity. Table I and Figures 1-8 show the results of our study of these preserved oocysts. Although there was some initial shrinkage of oocysts during the first year after embedding, probable compression of oocysts under the cover glass over time has caused the oocysts to swell slightly in the decade since they were last measured (Table I). Nonetheless, many oocysts on our original slides are still structurally intact and are as clearly visible after 11 years' preservation as when initially embedded (cf. Figs. 3-5 vs. 6-8).

When descriptions of new coccidians are presented to journals for review and publication, editors may one day require, as they do for descriptions of new helminth species, that types first be on deposit with nationally accredited museums. The methods we presented earlier (Marchiondo and Duszynski, 1978) may then be useful for those who work with oocysts as one way to produce type specimens (or at least syntypes) of coccidian oocysts.

\section{LITERATURE CITED}

BAndoni, S. M., AND D. W. DuszYnSKI. 1988. A plea for improved presentation of type material for Coccidia. Journal of Parasitology 74: 519-523.

Marchiondo, A. A., AND D. W DuszYnSKI. 1978. Permanent light microscopy slides of Eimeria nieschulzi oocysts. Journal of Parasitology 64: 163164. 